\title{
THE MECHANICS OF DRUMLIN FORMATION WITH PARTICULAR REFERENGE TO THE CHANGE IN PORE-WATER CONTENT OF THE TILL
}

\author{
By John Menzies \\ (Department of Geography, Brock University, St. Catharines, Ontario $\mathrm{L}_{2} \mathrm{~S}_{3} \mathrm{~A}_{1}$, Canada)
}

\begin{abstract}
Aвstract. Most drumlins are composed of till that appears similar in all characteristics to non-drumlin till. Evidence, however, in the form of till layer sequences and from palaeomagnetic Koenigsberger ratios indicate that drumlin till may have a slightly higher pore-water content at the time of lodgement than nondrumlin till. In order that deposited till remains at the ice-glacier-bed interface to initiate drumlin formation, it must undergo rapid geotechnical changes whereby its pore-water content is dissipated thereby increasing the shear strength of the till. Two mechanisms of pore-water removal are possible. Firstly, pore water may be removed from localized patches within a mobile layer of till at the ice-glacier-bed interface, thus creating nuclei of higher-strength till around which deforming till may adhere. Secondly, removal of water initially from the thin water film at the base of a glacier may result in increased pressure melting of the ice leading to till melt-out and subsequent loss of pore water from the deposited till. The loss of water at the glacier bed may be either via permeable subglacial deposits or bedrock, or within subglacial depressions.
\end{abstract}

RÉsumé. La mécanique de la formation des drumlins avec une référence particulière à la teneur en eau capillaire de la moraine. La plupart des drumlins sont composés de matériaux morainiques qui paraissent semblables dans toutes leurs caractéristiques aux matériaux morainiques hors drumlins. Des preuves cependant tirées de la forme des séquences des niveaux morainiques et des rapports paléomagnétiques de Koenigsberger, montrent que la moraine des drumlins peut avoir été légèrement plus riche en eau capillaire au moment de sa formation que la moraine hors drumlin. Pour que la moraine déposée reste à l'interface glace-lit rocheux pour entamer la formation de drumlins, elle doit subir de rapides changements géotechniques qui lui fassent perdre sa teneur en eau capillaire ce qui accroit sa résistance au cisaillement. Deux mécanismes de perte de capacité capillaire sont possibles. Tout d'abord, l'eau d'imbibation peut disparaître par des cheminements localisés dans un niveau mobile de moraine à l'interface glace-lit rocheux créant ainsi des noyaux de moraine de plus forte résistance auxquels la moraine en cours de déformation peut adhérer. Ensuite, la disparition de l'eau qui constituait le mince film d'eau à la base du glacier peut provoquer un accroissement du point de fusion de la glace conduisant à la fusion dans la moraine et par conséquent à la perte de capacité capillaire de la moraine déposée. La perte d'eau le long du lit rocheux peut se produire soit à travers de dépôts perméables sous glaciaires, ou le long du lit, ou à l'intérieur des dépressions sous glaciaires.

Zusammenfassung. Der Mechanismus der Drumlin-Bildung unter besonderer Berücksichtigung des Wechsels im Porenwassergehalt des Schuttes. Die meisten Drumlins bestehen aus Moränenmaterial, das in allen Charakteristiken dem Schutt ausserhalb der Drumlins ähnlich erscheint. Jedoch deuten Hinweise in der Form der Abfolge von Schuttschichten und aus paläomagnetischen Königsberger-Zahlen darauf hin, dass Drumlinschutt im Zeitpinkt seiner Ablagerung einen etwas höheren Porenwassergehalt hat als anderer Glazialschutt. Wenn abgelagerter Schutt an der Grenzfläche zwischen Eis und Gletscherbett verbleiben und die Drumlinbildung einsetzen soll, muss er schnelle geotechnische Veränderungen erfahren, bei denen sein Porenwassergahalt verringert und dadurch seine Scherfestigkeit erhöht wird. Zwei Mechanismen zur Beseitigung des Porenwassers sind möglich. Zunächst kann Porenwasser an örtlichen Flecken innerhalb einer beweglichen Schuttschicht an der Grenzfläche zwischen Eis und Gletscherbett verschwinden, wodurch Kerne festeren Schuttes entstehen, denen sich verformter Schutt anlagert. Andrerseits kann der beginnende Abzug von Wasser aus dem dünnen Wasserfilm am Untergrund eines Gletschers erhöhte Druckschmelze des Eises erzeugen, was zum Aussschmelzen von Schutt und nachfolgendem Verlust an Porenwasser im abgelagerten Schutt führt. Der Wasserverlust am Gletscherbett kann entweder durch durchlässige subglaziale Ablagerungen oder Untergrundsmaterialien oder aber über-subglaziale Einsenkungen erfolgen.

\section{INTRODUCTION}

It has been shown that the lodgement of till is strongly influenced by increases in the effective normal pressure at the base of a glacier (Boulton, [ $\left.{ }^{c} 1975\right]$, p. 23). Boulton has demonstrated that, with a relatively constant ice velocity, if the effective normal pressure increases, a critical level is attained beyond which glacial abrasion ceases and lodgement begins. If the mechanics of drumlin formation are to be understood in terms of patterns and processes of glacial deposition, it is necessary to discover how high effective normal pressures might be produced within the till that dominantly compose drumlins in order that a drumlin 
develops and withstands the high basal shear stresses at the ice-glacier-bed interface. In this paper two mechanisms are suggested whereby high effective normal pressures are produced due to rapid loss of water from (a) the deforming material at the glacier bed and (b) the water film at the sole of temperate glaciers.

Almost all drumlin theories have been developed from an initial premise that the till that will form the drumlin is already deposited and is in a position to be moulded, or that the till is very rapidly deposited in large amounts due to some unknown mechanism and can then be drumlinized. Previous theories all appear to have their beginning sometime after the initial event of till deposition has occurred. It is intended in this paper to attempt to suggest mechanisms whereby this initial event of till agglomeration may occur.

A large number of factors are involved in the formation of a drumlin. Some of these factors may be of more importance than others and some may be of importance at one or several stages in the formation of a drumlin. As Smalley and Unwin (1968, p. 377) have noted, the main problem in investigating drumlin formation is in choosing "the significant and avoiding the irrelevant" factors.

Several factors have been studied by the writer (Menzies, unpublished) and their possible interrelationships investigated. In the main it has been concluded that the till found within drumlins is similar in most aspects to the till in non-drumlin areas. Few relationships appear to exist between drumlins, drift thickness, and bedrock topography (Crozier, 1975; Trenhaile, 1975; Menzies, unpublished). It is therefore likely that the intricate relationships that may have developed between glacier ice, till, and water, in the subglacial zone, may be the most important set of factors in the initiation and final development of drumlins (cf. Smalley and Unwin, I968).

\section{Till DePosition}

Since till is the main constituent of drumlins, in an attempt to explain drumlin formation it becomes necessary to explain how till is deposited. Drumlin till does not appear to be fundamentally different from other till deposits. It may be assumed that up to a critical point the mechanism of drumlin till deposition should be similar to that for the deposition of nondrumlin till. The explanation of drumlin formation therefore hangs on the understanding of what is this critical point; when and how it is reached and why the response of the subglacial system to the ongoing process is in the form of drumlin development.

The mechanism of till deposition, under temperate and sub-polar ice masses, has been discussed by several writers (Peterson, unpublished; Boulton, 1970, 1971, [ ${ }^{\mathrm{c}}$ 1976]; Boulton and Paul, 1976; Mickelson, 1971; Nobles and Weertman, 1971; Goldthwait, [ ${ }^{1}$ I974]) who have generally agreed that basal till is gradually deposited by the release of debris from the ice in response to basal melting. This melting process, under active temperate ice sheets, is largely in the form of pressure melting. Nobles and Weertman (197 I, p. 122) have shown that heat sources available for melting at the base of an ice sheet are derived from geothermal sources $\left(c .35 \mathrm{cal} \mathrm{cm}^{-1}\right.$ year $^{-1}, 15 \mathrm{~kJ} \mathrm{~m}^{-1}$ year $\left.^{-1}\right)$, from heat transmitted through the ice from the atmosphere, from the heat of friction, and from latent heat sources, resulting in an average value of $80 \mathrm{cal} \mathrm{cm}^{-1}$ year-1 $\left(33 \mathrm{~kJ} \mathrm{~m}^{-1}\right.$ year-1). Depending on the percentage of debris within the ice, a rate of till deposition of between 0.5 and $3 \mathrm{~cm}$ year ${ }^{-1}$ might be expected to occur under normal rates of pressure melting.

In relation to drumlin till deposition, this rate of deposition appears to be rather low. Work by Goldthwait $\left(\left[{ }^{c}{ }_{1} 974\right]\right)$ and others on present-day glaciers in Alaska, has shown that till is deposited subglacially within the final few centuries before ice retreat from an area. A drumlin $50 \mathrm{~m}$ high, under normal rates of till deposition, would take therefore approximately i 600 to Io 000 years to build up; a time period contrary to Goldthwait's evidence. 


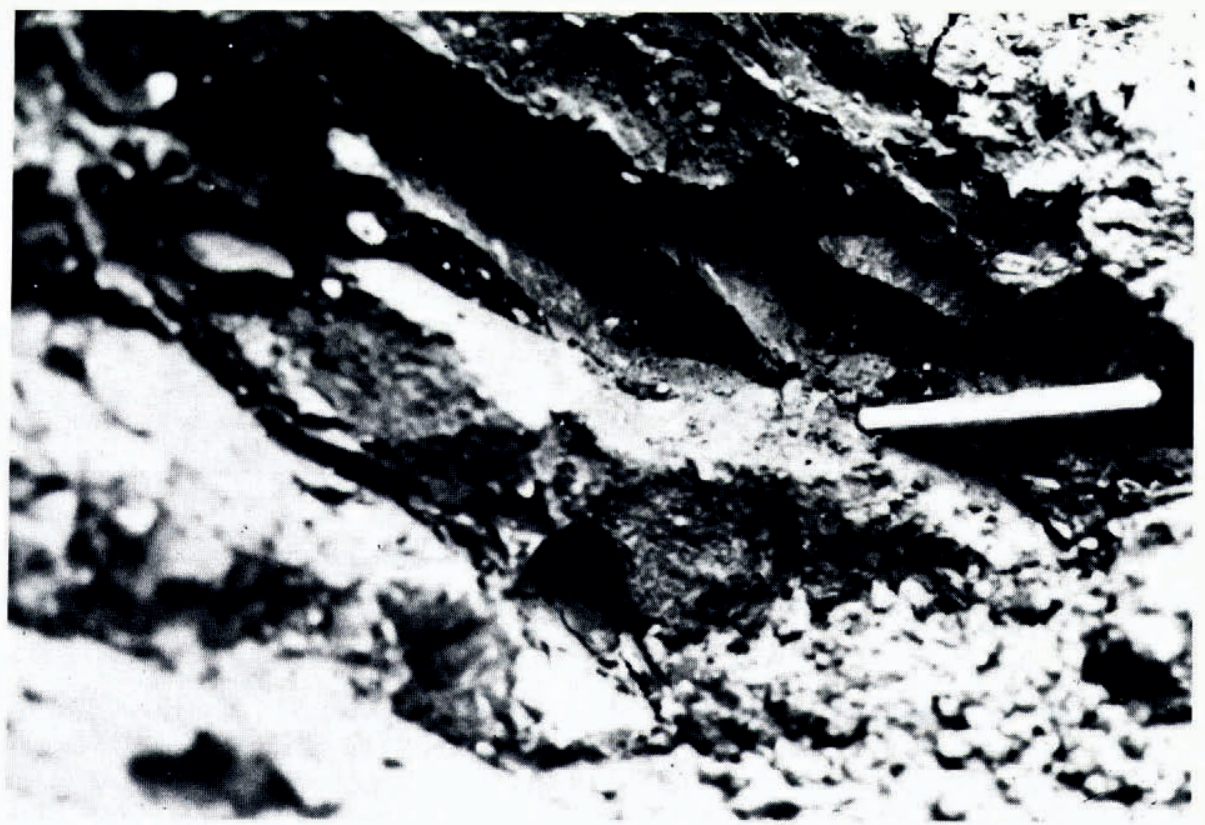

Fig. I. Till "layers" as revealed in a druplin till section, west-central Scotland ( $10 \mathrm{~cm}$ bar for scale).

\section{DRUMLIN TILL}

While examining drumlins in the Glasgow area of west-central Scotland the writer discovered several features associated with the internal material of these drumlins. These observations have led to the formulation of two possible mechanisms of drumlin formation.

Layers in the form of thin horizontal or slightly wavy partings of fine sand and silt were observed within drumlin till exposures throughout the Glasgow area (Fig. I) (Menzies, unpublished). These layers were of short horizontal amplitude normally extending from 5 to $70 \mathrm{~cm}$, they were lenticular in form with many features akin to current bedding as found in fluvial environments. It seems likely that these layers are indicative of localized deposition over the surface of a developing drumlin. The partings would appear to be indicative of shortdistance unconformities and as such to be erosional in origin. Measurements were taken from two drumlins revealing an average spacing range of 5 to $12 \mathrm{~cm}$ between layers (Virkkala, 195I) (Fig. 2).

Although it could not be established whether or not these layers were annual, it seems likely that they are at least minimal annual values if Goldthwait's concept of when till deposition occurs is correct. The tentative conclusion from this is that rates of till deposition on a drumlin were probably slightly above normal.

Further evidence of the nature of drumlin till deposition was supplied by palaeomagnetic investigations. In comparison with non-drumlin till in southern Ontario (Stupavsky and Gravenor, 1974), the Glasgow till showed, in a preliminary study, evidence of having been deposited in a fluid slurry with approximately a $10 \%$ higher percentage water content by weight (Fig. 3). This higher water content may be the result of greater pressure melting than normal in the basal layers of the ice resulting in higher rates of till deposition (cf. Boulton and Paul, 1976, p. I 79). The greater pressure melting may be due to higher rates of ice movement or a greater thickness of the ice mass (kinematic waves). 


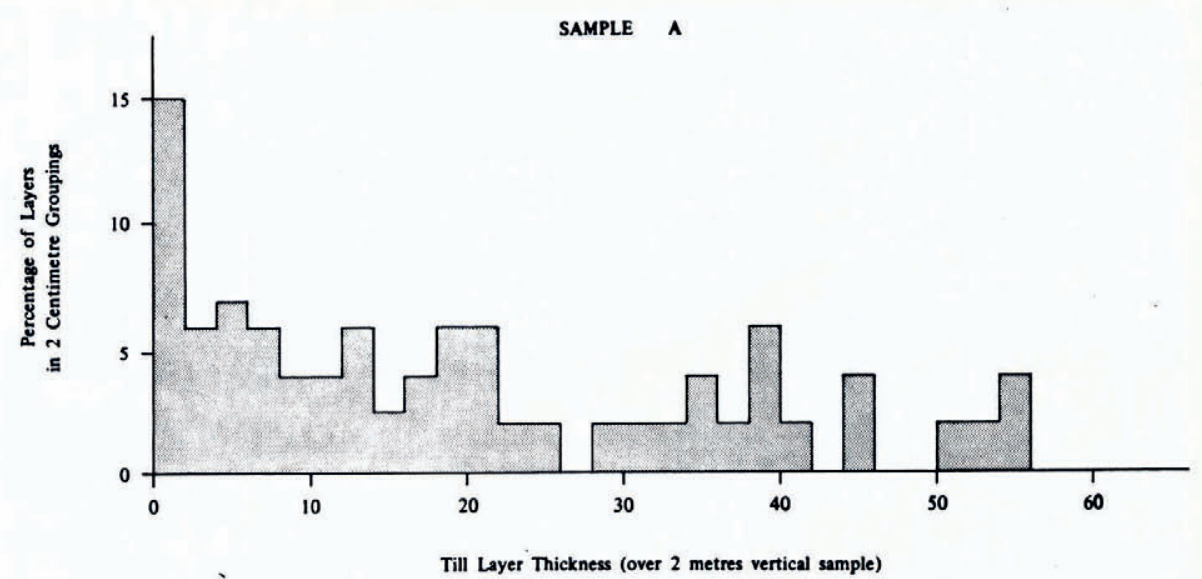

Fig. 2. A range of till "layer" dimensions as taken from a drumlin in the Glasgow area, west-central Scotland.

Using a technique similar to that devised by Gross and Moran (1971), pebble lithology isolines were superimposed upon a map of drumlin long-axis orientations (indicating the direction of major ice flow) in order to distinguish between areas of erosion and deposition. Where isolines run parallel to the long-axis orientation, no erosion has occurred, there being no change in the percentage of pebbles. Erosion has occurred where the isolines cross at right angles or obliquely to the long-axis orientation. From Figure 4 it can be seen that large area variations exist between areas where erosion appears to have dominated and others where net

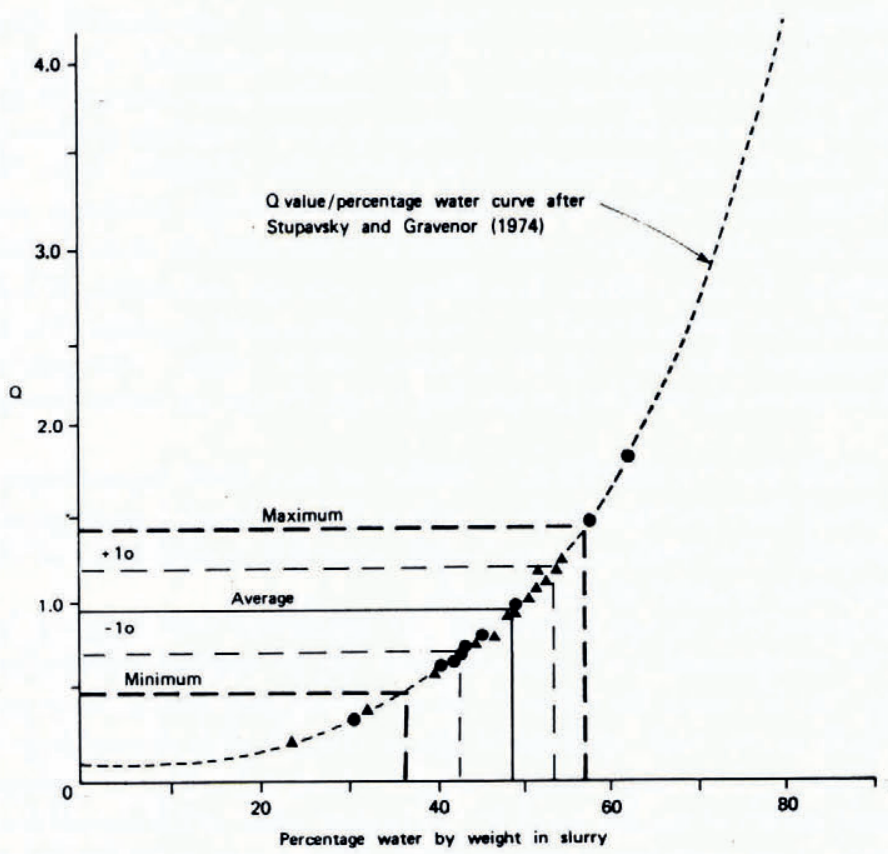

Fig. 3. A graph of Koenigsberger values $Q$ derived from palaeomagnetic measurements of drumlin till in the Glasgow area as compared to a $Q$ value/percentage-water curve presented by Stupavsky and Gravenor (1974). 
deposition seems to have occurred. Any drumlin theory developed must therefore allow for contemporaneous erosion and high rates of till deposition within close proximity to one another (cf. Muller, [ $\left.{ }^{\mathrm{c}}{ }_{1974}\right)$ ).

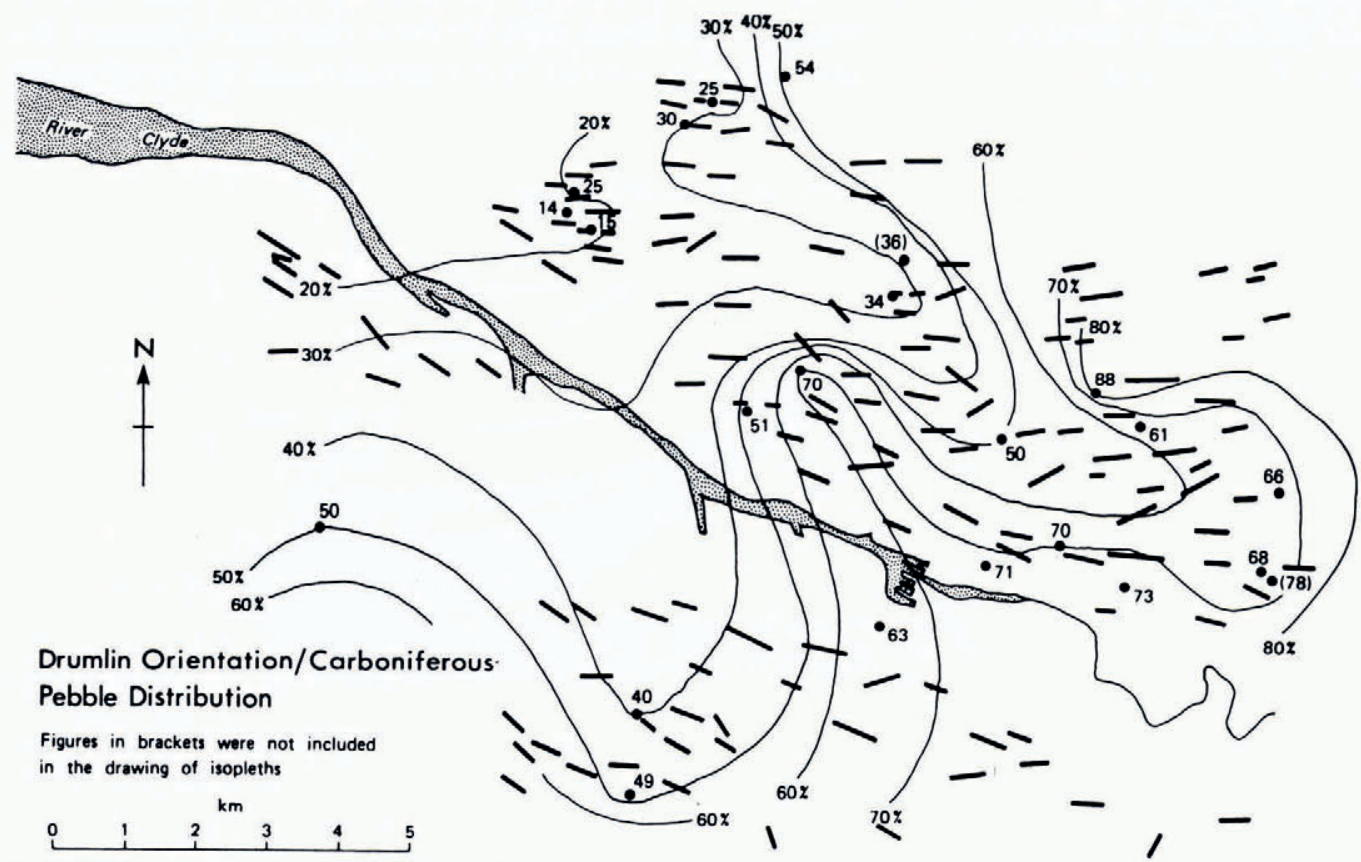

Fig. 4. A diagram showing the relationship between drumlin long axes (indicative of the direction of maximum ice movement) and the percentage variation of Carboniferous pebbles within the till. Where drumlin long axes parallel the pebble isopleths little erosion has occurred. Where the long axes cross the isopleths erosion has been predominant.

THE CONGENTRATION OF DEBRIS IN BASAL ICE

To achieve a high rate of till deposition either over a broad area or in localized patches, it is necessary for the basal ice to be either heavily choked with debris over a considerable area or for very high concentrations of debris to exist in specific parts of the basal ice. Recent observations beneath temperate ice sheets have revealed that dirt layers in the basal ice rarely exceed $100 \mathrm{~m}$ before clean, debris-free ice is found (Boulton and others, I974, p. I36; Boulton, 1976 , p. 227). However, close to the margins of present-day ice-sheets and glaciers that have polar snouts, large localized concentrations of debris have been observed (Goldthwait, I95 I ; Souchez, 1967, 1971; Boulton, 1968, 1971; Moran, 1971; Hooke, 1973). The evidence of these debris concentrations has been in the form of shear moraines and flow tills. Moran (197 I, p. I34), Hooke (1973, p. 424) and Clayton and Moran ([ $\left.{ }^{c_{1}}{ }_{974}\right]$, p. 93) have argued that at point $\mathrm{A}$ in Figure 5, for example, a large number of basal debris bands will stack themselves one on top of the other as a result of differential changes in ice velocity. If this stacking process does occur at this juncture between the polar and temperate ice, a large zone of concentrated dirt would appear to accumulate. With such a localized concentration, a state is reached whereby large deposits of till could melt out over small areas, thus producing an ideal stage for drumlin initiation.

It is the opinion of several workers (Hooke, 1973; Clayton and Moran, [ ${ }^{\mathrm{c}}$ 1974]; Andrews, [ ${ }^{\mathrm{I}}$ I975]; Boulton and Paul, 1976) that the major Quaternary ice sheets may have had polar snouts. Boulton and Paul (1976, p. I65) have argued, for example, that areas of hummocky 
moraine and dead-ice topography, typical of parts of Highland Britain, are intrinsically associated with ice sheets having polar snouts.

A further possibility that might allow large concentrations of debris in the basal ice zone would be short-term changes in the basal ice temperatures. Baranowski (1970), Shaw (1972) and Shaw and Freschauf (1973) theorized that if the zero isotherm descended beneath the base of the ice and into the underlying erodable material, this material could be incorporated

\section{Debris at Base of Glacier}

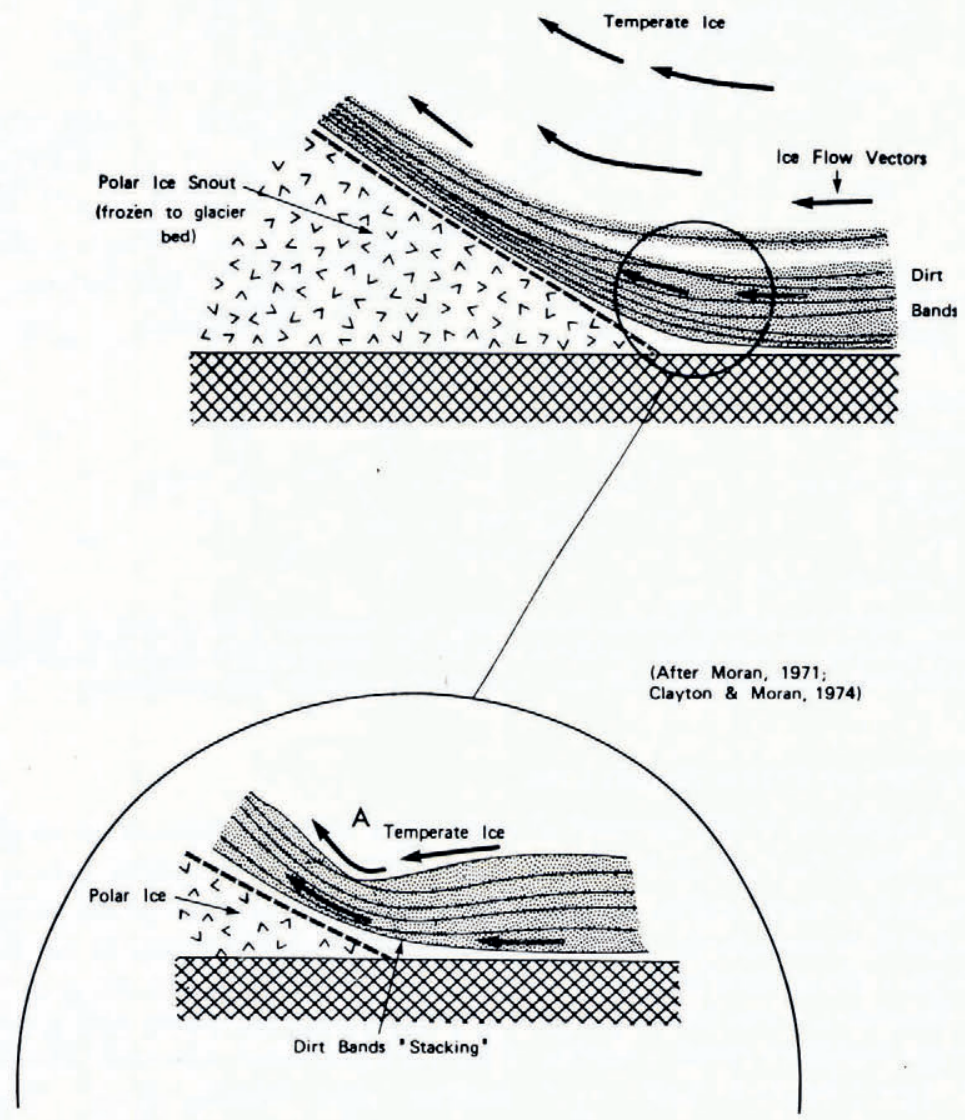

Fig. 5. The possible location where the stacking of debris bands within the ice at the base of a glacier might occur.

into the basal ice and then transported. If such basal ice temperature changes occurred in areas of thick underlying erodable material, large concentrations of debris would be incorporated into the ice, and thus subsequently high rates of till deposition might occur.

Changes in basal ice temperatures may be either the result of climatic variations or thickness variations in the ice sheet. Ice sheets can be expected to thin due to ice extension on entering a less constricted area, due to kinematic waves (Paterson, 1969), to surging (Weertman, 1962, 1966), or to changes in the nature of the underlying bed (Moran, 1971; Boulton, [ $\left.{ }^{\mathrm{c}} \mathrm{I} 974\right]$; Boulton and others, 1974$)$. 


\section{Postulated MEChANISM OF FORMATION}

In order that a drumlin can remain at the interface between the ice and the glacier bed, the drumlin must be able to withstand the shear stresses applied to it by the overlying and moving ice mass. Furthermore if a drumlin is to remain at this interface, the shear strength $S_{\mathrm{m}}$ of the material composing the drumlin must be higher than the shear stresses applied on the drumlin material by the ice. Observations on tills deposited by present-day glaciers indicate that the tills have a very high moisture content and are in the form of slurries that are easily deformed and squeezed (Okko, I955; Paterson, unpublished; Boulton, 1970; Mickelson, I971 ; Boulton and Dent, I974; Boulton and others, 1974; Clapperton, 1975). In order that such till may be incorporated within a drumlin and be able to withstand the considerable shear stresses applied by the ice, it must undergo critical changes in its rheological properties. The till must change from being a fluid mixture of debris, water, and ice to a non-fluid material of low water and ice content.

Two possible mechanisms may be suggested by which till could form into non-fluid agglomerations. First, these agglomerations may develop from within a very thick mobile layer of till lying between the ice and underlying glacier bed, or secondly, these agglomerations may be the result of localized deposition caused by changing conditions in the subglacial zone. In the second mechanism no other surrounding till deposits need occur as was noted in northern Canada (Dean, 1953) and central Sweden (Lundqvist, I970).

\section{RHEOLOGIGAL CONSIDERATIONS}

In both possible mechanisms of formation, a basic principle of soil mechanics is applicable in the change from fluid slurry-like till to stable, resistant till. The shear strength of a material can be defined as the inherent resistance of a material to deformation. Shear streng'th can be defined in terms of Coulomb's equation:

$$
S_{\mathrm{m}}=C+P \tan \phi,
$$

where $C$ is cohesion, $P$ is pressure on the material, and $\phi$ is the angle of internal friction. If the voids in the material are filled with a liquid under stress $u_{\mathrm{w}}$, one part $p$ of the pressure $P$ is carried by the solid particles which have a finite $\tan \phi$ value, whereas the balance $\left(P-u_{w}\right)$ is carried by the liquid phase which has a $\tan \phi$ of zero. Terzaghi (r943) derived the term "effective stress" to account for this part, and since

$$
p=P-u_{\mathrm{w}},
$$

he thus derived a "revised Coulomb equation"

$$
S_{\mathrm{m}}=C+\left(P-u_{\mathrm{w}}\right) \tan \phi,
$$

or

$$
S_{\mathrm{m}}=C+p \tan \phi .
$$

It can be seen therefore that the shear strength of a material is controlled by the relationship between interparticle pressures $p$ and pore pressures $u_{\mathrm{w}}$. In any saturated, unconsolidated material, the particle-grain structure is more compressible than the pore water, causing excess, positive, pore-water pressure. When stress is applied, this excess pore-water pressure begins to dissipate immediately by causing the water in the voids to flow along a path of least resistance toward an area of lower pressures. With the drainage of this pore water, increasing amounts of the applied stress are transferred to the particles. This change in the application of the stress results in an increase in interparticle stresses $p$ thereby causing an increase in the shear strength of the material. A further increase in applied stress would cause a sequential increase in shear strength and further pore-water dissipation. 
At a specific stress level depending on its grain-size distribution and grain shapes, a material such as till may become dilatant (Reynolds 1885; Mead, I925; Smalley and Unwin, I968; Boulton and others, 1974). Dilatancy may be regarded as a property inherent in a material, occurring when the applied stress causes the particle-grain structure to expand due to movement of particles in relation to one another, from side-to-side contact to point-to-point contacts. The effect on the material is usually manifested in an increase in volume, resulting in an increase in void spaces. If a saturated material becomes dilatant it has been shown that pore-water pressures become negative, causing a subsequent reduction in pore-water dissipation (Terzaghi and Peck, $\left[{ }^{\mathrm{c}}{ }_{1967}\right]$ ).

The most important consideration in the increase in shear strength of any saturated material is the amount and rate at which excess pore-water pressure can be dissipated and stress transferred to the grain structure. As Clayton and Moran ([ $\left.{ }^{\mathrm{c}} \mathrm{I}_{974}\right]$ ) have noted, "the most rapid dissipation of excess pressure occurs in coarse-textured sediments where the flow path between areas of high and low pressure is short. The least rapid dissipation occurs in fine-textured sediments where the flow path is considerably longer". A further consideration is the compressibility of the material, since coarse-grained sediments are much less compressible than fine-grained ones.

\section{Rheological changes in till}

From the above observations the application of stresses to saturated till can be considered. Since the matrix of till is normally a fine-textured material it seems likely that flow paths will be exceedingly long and thus a tendency for fairly high excess pore-water pressure to exist will persist when till is overridden by glacier ice. Boulton and others (I974, P. I4I) have shown that where no or limited drainage occurs in a fine-grained till, excess pore pressures being undissipated will cause a reduction in till shear strength, finally leading to the till approaching. a highly fluid state. However, if the till were to overlie a coarse-textured material or a subglacial drainage route either of which could act as areas of pressure dissipation, then this fine-grained material may become less fluid, increase its strength, and no longer have an excess pore-water pressure (Moran, I97 I ; Clayton and Moran, [ ${ }^{\mathrm{C}}$ I974], p. 94; Boulton and others, 1974, p. 140).

\section{TWO MECHANISMS OF DRUMLIN INITIATION}

\section{Mechanism I}

If till has been accumulating beneath a glacier and above an impermeable bed such as unfractured bedrock or bedrock of low hydraulic conductivity, a state may be reached where excess pore-water pressures are produced. This may occur either due to increased subglacial melting and thus higher water content in the till or increased ice pressures due to ice advance over the deposited till.

It is envisaged that at this stage, with the till being fluid beneath the glacier, the initial event in drumlin formation may occur. If parts of the fluid till were to be halted (see below) the surrounding till would rapidly encompass and plaster around this stationary patch. Any glaciological changes that would affect the whole area of flowing till such as decreases in ice pressure must therefore be discarded. Only a mechanism that would cause localized patches of till to become non-fluid while the remaining parts of the till remain fluid can be considered. Therefore it might be visualized that in large areas of till underlain with sands and gravels where large-scale general pore-water dissipation has occurred, no drumlins would occur, there being only a thick blanket of consolidated till (e.g. Cheshire Plain, England).

Since the till is flowing as a result of the stress applied by the ice resulting in excess porewater pressures in the till, any method of dissipating such pressures will cause the rheological 


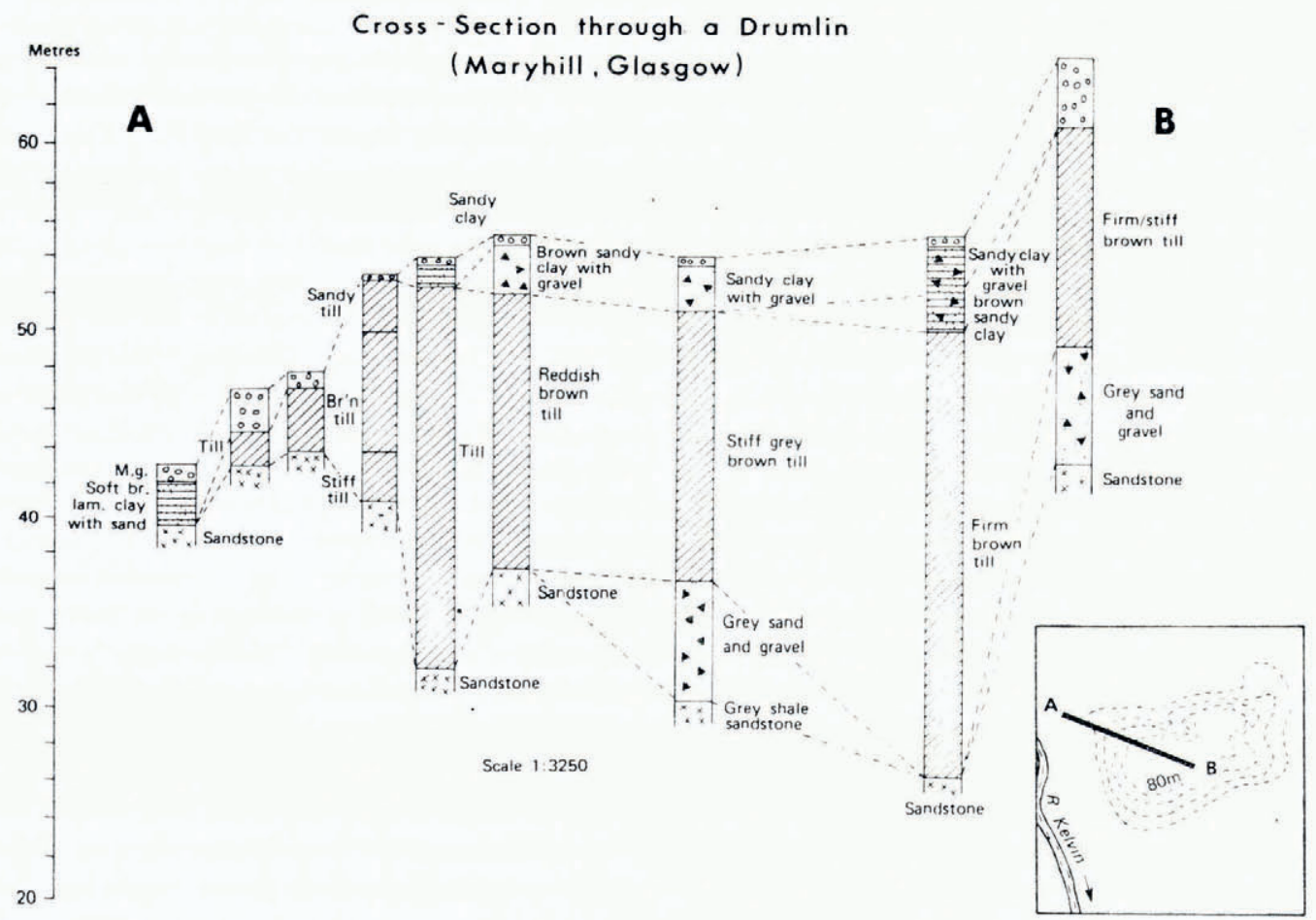

Fig. 6. A cross-section through a drumlin revealing localized deposits of permeable sands and gravels beneath consolidated drumlin till.

change noted above to occur in the till. It has already been demonstrated by Moran (I97I) and Boulton and others (1974), that areas of till underlain by coarse sands and gravels would allow drainage of this pore water. Also zones of highly shattered bedrock or jointed bedrock (Glückert, 1973) would act as areas of pore-water dissipation. Subglacial bedrock or glacierbed depressions transverse to ice movement (Gjessing, I966) and subglacial water channels would also act as areas of low pressure to which the pore water would migrate. Within the Glasgow district, by using extensive bore-log coverage across the drumlin field, the writer found that in several areas large spreads of coarse sands and gravels underlie the drumlins (Fig. 6). Also deep, transverse bedrock channels cross the drumlin field and appear to be connected with a subglacial melt-water drainage system (cf. Wright, 1973, fig. 2, p. 254; personal communication from I. J. Smalley in I974).

It is postulated that if till is flowing beneath an ice mass, small local areas or narrow zones of low pressure could act as locations where the till could become non-fluid and develop, if the agglomeration was of sufficient size, into a proto-drumlin. The non-fluid patches of till would act as an obstruction around which more till would accrete.

\section{Mechanism 2}

Glaciological investigations in bore holes (Gow, 1963) and directly at the glacier sole (Kamb and LaChapelle, I964; Vivian and Bocquet, r973) have revealed that the theory of glacier sliding proposed by Weertman (1964) and Lliboutry (1968) is essentially correct. In order that a temperate ice mass can move over its bed a film of water is necessary at the interface between the moving ice mass and the glacier bed. Much discussion has gone on as 
to whether this water is in sheets or discrete channels. When this water film is broken down or removed, the ice mass grounds onto the glacier bed: friction between the ice and its bed changes from approximately zero to a large figure, causing increased pressure melting to occur. At this stage of pressure melting, any debris in the basal ice is melted out and deposited. By pressure melting the ice itself creates a water film thereby reducing friction, and ice movement by basal-slip continues.

If this process of removal of water film and pressure melting could occur in areas beneath basal ice in which large concentrations of debris existed, large agglomerations of till could be rapidly produced in localized patches.

Moran (1971) and Hooke (1973), as already noted, have envisaged and observed large concentrations of debris in the areas up-glacier of the glacier snout (Fig. 5). If these large accumulations were to be melted out then large amounts of till would be available for drumlin formation. If the lubricating water film could be drained into a permeable bed beneath the ice or into subglacial melt-water channels, or if the water supply to the film could be reduced or cut off, then the ice would be grounded and in a state of pressure melting. At this stage, with large amounts of debris being deposited in this subglacial but marginal position, excess pore-water pressures would immediately be built up in the deposited till. If the mechanism that removed the water film could operate to remove the pore water, as envisaged in Mechanism I, then patches of till would become non-fluid. It then follows that if the till agglomeration were of sufficient size, a proto-drumlin could be created.

\section{The proto-drumlin}

Once the till has become non-fluid and becomes an obstruction at the basal-ice-glacier-bed interface two possibilities may occur. First, if the agglomerated till is of too small a size or becomes rapidly dilatant (Radhakrishna and Klym, I974), thus again increasing its pore-water content, the till will be eroded or fluidized and removed. Secondly, if the agglomerated till is large enough to withstand the shear stresses applied by the ice and does not rapidly become dilatant, the till may remain in position. This second possibility is the state of initial drumlin formation.

As the initial mass of till continues to lose pore water, the till consolidates and its shear strength rapidly rises. In time, as this process of consolidation proceeds, the stability of the proto-drumlin at the ice-glacier-bed interface increases.

The proto-drumlin, once established, begins to act as a core or nucleus around which more till accumulates. As the till continues to be deposited, the size of the drumlin increases, thus leading to even greater stability at the subglacial interface. It can be concluded that at this stage drumlin development will continue uninterrupted, provided no adverse changes occur within or to the subglacial environment, resulting in the characteristic drumlin form being produced.

\section{Concluding Remarks}

In order that drumlins remain at the ice-glacier-bed interface it is necessary that the till composing the drumlins be able to withstand the shear stresses imposed by the moving glacier. From the Coulomb-Terzaghi Equation (3) when applied to slurry-like till, it can be noted that with reduction in pore-water pressures, inter-particle pressures will increase with concomitant increase in till shear strength.

Two mechanisms have been put forward to allow such pore-water removal. Of the two mechanisms, the first is, in the writer's opinion, the most common possibility since drumlins are most usually associated with areas of thick drift. However, as already mentioned, drumlins do occur in areas of bare bedrock, or thin drift. It would seem likely therefore that in such areas the second mechanism would apply. 
From the many observations made within drumlin fields throughout the world and from the writer's own research a considerable body of data exists with regard to drumlin internal composition and the nature of sub-drumlin materials and bedrock topography that would appear to indicate the validity of these mechanisms of pore-water removal. The mechanism of pore-water dissipation has been shown, from field evidence, to function within the glacier system causing changes in the pattern of glacial sedimentation (Boulton and others, 1974). However further research to test these mechanisms with regard to drumlin formation is required both in present-day glaciated areas and in Quaternary drumlin fields.

\section{Acknowledgements}

I am particularly grateful to I. J. Smalley and A. Thomas who gave encouragement and helpful criticism in their discussions on drumlin formation. I also wish to thank the technical staff of the Geography Department, Brock University, for their assistance in typing and cartography.

\section{MS. received 12 fuly 1978 and in revised form I November 1978}

\section{REFERENCES}

Andrews, J. T. [ ${ }^{\mathrm{C}}{ }_{1975 .]}$ Glacial systems. An approach to glaciers and their environments. North Scituate, Mass., Duxbury Press. (Environmental Systems Series.)

Baranowski, S. 1970. The origin of fluted moraines at the fronts of contemporary glaciers. Geografiska Annaler, Vol. 52A, No. I, p. 68-75.

Boulton, G. S. 1968. Flow tills and related deposits on some Vestspitsbergen glaciers. Fournal of Glaciology, Vol. 7, No. 51, p. 391-412.

Boulton, G. S. 1970. On the origin and transport of englacial debris in Svalbard glaciers. Journal of Glaciology, Vol. 9 , No. 56, p. $213-29$.

Boulton, G. S. 1971. Till genesis and fabric in Svalbard, Spitzbergen. (In Goldthwait, R. P., ed. Till: a symposium. [Columbus], Ohio, Ohio State University Press, p. 41-72.)

Boulton, G. S. [ ${ }^{\mathrm{c}} \mathrm{I}$ 974.] Processes and patterns of glacial erosion. (In Coates, D. R., ed. Glacial geomorphology. Binghamton, N.Y., State University of New York, p. 41-87. (Publications in Geomorphology.))

Boulton, G. S. [ ${ }^{\mathrm{C}}{ }_{1}$ 975.] Processes and patterns of subglacial sedimentation: a theoretical approach. (In Wright, A. E., and Moseley, F., ed. Ice ages: ancient and modern. Liverpool, Seel House Press, p. 7-42. (Geological Journal Special Issue No. 6.))

Boulton, G. S. 1976. [Comments made in panel discussion.] (In Till-its genesis and diagenesis. Materials of symposium of Commission on Genesis and Lithology of Quaternary Deposits (INQUA), Poland 1975. Poznan, Uniwersytet $\mathrm{im}$. Adama Michiewicza, p. 227-28. (Uniwersytet im. Adama Mickiewicza w Poznaniu. Seria Geografia, Nr. 12.))

Boulton, G. S. [ ${ }^{c}{ }_{1976}$.] The development of geotechnical properties in glacial tills. (In Legget, R. F., ed. Glacial till. An interdisciplinary study. [Ottawa], Royal Society of Canada in co-operation with the National Research Council of Canada, p. 292-303. (Royal Society of Canada Special Publications, No. 12.))

Boulton, G. S., and Dent, D. L. 1974. The nature and rates of post-depositional changes in recently deposited till from south-east Iceland. Geografiska Annaler, Vol. 56A, Nos. 3-4, p. 121-34.

Boulton, G. S., and Paul, M. A. 1976. The influence of genetic processes on some geotechnical properties of glacial tills. Quarterly Journal of Engineering Geology, Vol. 9, No. 3, p. 159-94.

Boulton, G. S., and others. 1974. Subglacial shearing and crushing, and the role of water pressures in tills from south-east Iceland, by G. S. Boulton, D. L. Dent, and E. M. Morris. Geografiska Annaler, Vol. 56A, Nos. 3-4, p. $135-45$.

Clapperton, C. M. 1975. The debris content of surging glaciers in Svalbard and Iceland. Fournal of Glaciology, Vol. I4, No. 72, p. 395-406.

Clayton, L., and Moran, S. R. [ [ ${ }^{1}$ 1974.] A glacial process-form model. (In Coates, D. R., ed. Glacial geomorphology. Binghamton, N.Y., State University of New York, p. 89-119. (Publications in Geomorphology.))

Crozier, M. J. 1975. On the origin of the Peterborough drumlin field: testing the dilatancy theory. Canadian Geographer, Vol. 19, No. 3, p. $18 \mathrm{i}-95$.

Dean, W. G. 1953. The drumlinoid landforms of the "Barren Grounds", N.W.T. Canadian Geographer, [Vol. I], Nu. 3, p. 19-30.

Gjessing, J. 1966. On 'plastic scouring' and 'subglacial erosion'. Norsk Geografisk Tidsskrift, Bd. 20, Ht. I-2, $1965-66$, p. $1-37$.

Glückert, G. 1973. Two large drumlin fields in central Finland. Fennia, 120. 
Goldthwait, R. P. 1951. Development of end moraines in east-central Baffin Island. Journal of Geology, Vol. 59, No. 6 , p. $567-77$.

Goldthwait, R. P. [ ${ }^{2}$ I 974.$]$ Rates of formation of glacial features in Glacier Bay, Alaska. (In Coates, D. R., ed. Glacial geomorphology. Binghamton, N.Y., State University of New York, p. $163-85$. (Publications in Geo-

Gow, A. J. 1963. Results of measurements in the 309 meter bore hole at Byrd Station, Antarctica. Fournal of Glaciology, Vol. 4 , No. 36, p. $77 \mathrm{r}-84$.

Gross, D. L., and Moran, S. R. 1971. Grain-size and mineralogical gradations within tills of the Allegheny Plateau. (In Goldthwait, R. P., ed. Till: a symposium. [Columbus], Ohio, Ohio State University Press,

p. 25I-74.)
Hooke, R. L. 1973. Structure and flow in the margin of the Barnes Ice Cap, Baffin Island, N.W.T., Canada. Journal of Glaciology, Vol. 1 2, No. 66, p. 423-38.

$\mathrm{Kamb}$, W. B., and LaChapelle, E. R. 1964. Direct observation of the mechanism of glacier sliding over bedrock. Fournal of Glaciology, Vol. 5, No. 38, p. $159-72$.

Lliboutry, L. A. 1968. General theory of subglacial cavitation and sliding of temperate glaciers. Fournal of Glaciology, Vol. 7, No. 49, p. 21-58.

Lundqvist, J. 1970. Studies of drumlin tracts in central Sweden. Acta Geographica Lodziensia, No. 24, p. 31 7-26.

Mead, W. J. 1925. The geologic rôle of dilatancy. Journal of Geology, Vol. 33, No. 7, p. 685-98.

Menzies, J. Unpublished. The glacial geomorphology of Glasgow with particular reference to the drumlins. [Ph.D. thesis, University of Edinburgh, r 976.$]$

Mickelson, D. M. 1971. Glacial geology of the Burroughs Glacier area, southeastern Alaska: Ohio State University. Institute of Polar Studies. Report No. 40.

Moran, S. R. r971. Glaciotectonic structures in drift. (In Goldthwait, R. P., ed. Till: a symposium. [Columbus], Ohio, Ohio State University Press, p. 127-48.)

Muller, E. H. [' ${ }^{1}$ 974.] Origins of drumlins. (In Coates, D. R., ed. Glacial geomorphology. Binghamton, N.Y., State University of New York, p. $187-204$. (Publications in Geomorphology.)).

Nobles, L. H., and Weertman, J. I971. Influence of irregularities of the bed of an ice sheet on deposition rate of till. (In Goldthwait, R. P., ed. Till: a symposium. [Columbus], Ohio, Ohio State University Press, p. I $17-26$.

Okko, V. 1955. Glacial drift in Iceland, its origin and morphology. Bulletin de la Commission Géologique de Finlande, No. 170.

Paterson, W. S. B. 1969. The physics of glaciers. Oxford, etc., Pergamon Press. (The Commonwealth and International Library. Geophysics Division.)

Peterson, D. N. Unpublished. Glaciological investigations on the Casement Glacier, southeast Alaska. [Ph.D. thesis, Ohio State University, 1969.]

Radhakrishna, H. S., and Klym, T. W. 1974. Geotechnical properties of a very dense glacial till. Canadian

Geotechnical fournal, Vol. I i, No. 3, p. 396-408.
Reynolds, O. 1885. On the dilatancy of media composed of rigid particles in contact. Philosophical Magazine, Fifth Ser., Vol. 20, No. 127, p. 469-81.

Shaw, J. 1972. Sedimentation in the ice-contact environment, with examples from Shropshire (England). Sedimentology, Vol. 18 , Nos. 1-2, p. 23-62.

Shaw, J., and Freschauf, R. C. 1973. A kinematic discussion of the formation of glacial flutings. Canadian Geographer, Vol. 17 , No. I, p. 19-35.

Smalley, I. J., and Unwin, D. J. 1968. The formation and shape of drumlins and their distribution and orientation in drumlin fields. Fournal of Glaciology, Vol. 7, No. 51, p. 377-90.

Souchez, R. A. 1967 . The formation of shear moraines: an example from south Victoria Land, Antarctica.

Journal of Glaciology, Vol. 6, No. 48, p. 837-43.
Souchez, R. A. r971. Ice-cored moraines in south-western Ellesmere Island, N.W.T., Canada. Fournal of Glaciology, Vol. 10, No. 59, p. 245-54.

Stupavsky, M., and Gravenor, C. P. 1974. Water release from the base of active glaciers. Geological Society of America. Bulletin, Vol. 85 , No. 3 , p. $433-36$.

Terzaghi, K. 1943. Theoretical soil mechanics. London, Chapman and Hall; New York, John Wiley and Sons, Inc.

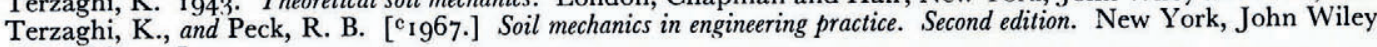
and Sons, Inc.

Trenhaile, A. S. 1975. The morphology of a drumlin field. Annals of the Association of American Geographers, Vol. 65 ,

No. 2, p. 297-312.
Virkkala, K. 1951. Glacial geology of the Suomussalmi area, east Finland. Bulletin de la Commission Géologique de Finlande, No. 155 .

Vivian, R. A., and Bocquet, G. 1973. Subglacial cavitation phenomena under the Glacier d'Argentière, Mont Blanc, France. Fournal of Glaciology, Vol. 12, No. 66, p. 439-5 I.

Weertman, J. 1962. Catastrophic glacier advances. Union Géodésique et Géophysique Internationale. Association Internationale d'Hydrologie Scientifique. Commission des. Neiges et des Glaces. Colloque d'Obergurgl, 10-9-18-9 1962, p. 31-39. (Publication No. 58 de l'Association Internationale d'Hydrologie Scientifique.)

Weertman, J. 1964. The theory of glacier sliding. Journal of Glaciology, Vol. 5, No. 39, p. 287-303.

Weertman, J. 1966. Effect of a basal water layer on the dimensions of ice sheets. Fournal of Glaciology, Vol. 6, No. 44 , p. $189-205$.

Wright, H. E., jr. 1973. Tunnel valleys, glacial surges, and subglacial hydrology of the Superior lobe, Minnesota. Geological Society of America. Memoir 1 36, p. $251-76$. 